\title{
AGRICULTURAL PRODUCTIVITY IN POLAND IN THE CONTEXT OF STRUCTURAL CHANGES IN THE SECTOR IN 2002-2016
}

\author{
Ryszard Kata, PhD, Associate Professor ${ }^{1}$
}

Faculty of Economics, University of Rzeszów

\begin{abstract}
This paper attempts to analyse the changes in labour and land productivity in agriculture in Poland resulting from changes to the production structures in this sector, particularly changes in the relationships between production factors, i.e. land, labour and capital. The analysis covered the years 2002-2016. It was found that this period saw important changes in agriculture expressed in the concentration of agrarian structure and the progressive substitution of land and labour by capital, which was reflected in the increase of work technical equipment and the rate of technical progress. There was also a progressive outflow of some of the labour resources from agriculture. A positive correlation between the productivity of land and labour and the said structural changes in agriculture was found.
\end{abstract}

Key words: agriculture, production factors, productivity of land and labour JEL codes: Q10, Q18

\section{INTRODUCTION}

In terms of utilised agricultural area (UAA) and labour resources in agriculture, Poland has relatively high potential to accomplish its goals in this sector. Regardless of changes in agricultural policy, production and economic results remain the most important objectives of agriculture. This involves achieving the amount and quality of agricultural products demanded by the market and ensuring appropriate income for farmers (Dzun, 2012). Achieving this goal depends not only on the amount of production factors held in agriculture, but also on their effective use in production processes.

In economics, the category of efficiency is of fundamental significance and touches on the problem of managing rare resources and optimising their use for the creation of goods and services. Agricultural productivity can be regarded in the context of the productivity of production factors or the profitability of agricultural activities, i.e. taking into account the costs (Czyżewski and Staniszewski, 2016). Productivity is the relationship between the amount of products, i.e. production results and the amount of production factors used in the production process, i.e. inputs (Woś, 1984). It can also be expressed as the value of production obtained from a unit of a particular input.

A number of determinants of agricultural productivity can be distinguished, from the quality of the agricultural production area, to macroeconomic determinants (economic trends, price scissors, foreign trade etc.), to external factors. Of the last, a special role is played by agricultural production structures, defined as the arrangement and mutual relationships

${ }^{1}$ Corresponding author: Cwiklińskiej 2, 35-601 Rzeszów, Poland, rdkata@ur.edu.pl, +4817 8721604 
between production factors and the results of their use. These structures can have many dimensions, such as production structure, i.e. the share of plant and animal production or the share of a given production type in the production value. According to Czyżewski and Staniszewski (2016), the productivity level of individual inputs largely depends on their mutual relationships.

This paper focuses on the relationship between production structures and land and labour productivity in agriculture. Changes in production structures (structural changes) should be understood as changes in the volume of resources of land and labour factors in agriculture, changes in their mutual relationships and the correlation of these resources with the capital factor. These relationships will be considered at the level of the whole sector. The objective of this paper is to analyse and evaluate the direction and scale of structural changes in 2002-2016 and to determine whether these changes were connected with the increase in land and labour productivity.

\section{THEORETICAL BACKGROUND}

Studies on the influence of changes in production structures on the level of agricultural productivity and potential determinants of these changes have been conducted in various places in the world for many years. Huffman and Evenson (2001) demonstrated that in the US the specialisation and concentration of production and farmers' access to non-farming sources of income influenced the overall productivity of resources in agriculture. Wang, Schimmelpfennig and Fuglie (2012) studied the determinants of the total productivity of production factors in European agriculture and found the declining significance of the labour factor in their structure. Vandermeulen, Mettepenningen and Calus (2010) demonstrated that the trend of structural changes in Belgian agriculture (the region of Flanders), similarly to those in all Western European agriculture, is towards larger farms and lower employment. These changes are bringing increased productivity, but also specific social and environmental consequences, which are often unfavourable when the structural changes lead to the narrow specialisation of farms and the industrialisation of agriculture.
Capital resources are increasingly important in boosting agricultural productivity (Fuglie and Rada, 2013; Wang et al., 2015). Through investments, this factor contributes to increasing the technical quality of work technical equipment and the rate of technological progress, which favours higher labour efficiency and land productivity (Pawlak, 2016; Kusz and Misiak, 2017). An important role in land and labour productivity is also played by innovation and broadly understood biological and technological progress in agriculture (Wicki, 2016).

In the context of production factors in agriculture, structural changes can serve several objectives at the same time and are usually interconnected. The changes in the production structures of agriculture which favour improved land and labour productivity are:

- the concentration of agrarian structure, expressed in the increase in the average area of an agricultural holding and the higher share of medium-sized and large farms (e.g. more than 15 ha of UAA) in the total number of farms and utilised agricultural area,

- the constantly progressing substitution of labour and land by capital inputs,

- the concentration of labour resources in relation to the land factor.

However, determining the influence of changes in the specific production structures on the productivity level of production factors in agriculture is very difficult, as productivity is determined by a number of factors, including the relationships of prices on the market, which is of particular significance for production expressed in monetary units.

\section{MATERIALS AND METHODS}

The values of final output and market output per unit of a given resource, i.e. ha of UAA and AWU were assumed as measures of land and labour productivity. Capital inputs and production volume were analysed in current prices and fixed prices, by means of a deflator - agricultural production price index (as a price deflator for final output and market output) and the price index for investment outlays (as a capital expenditure deflator). The study covered the years 2002-2016. Statistics from Central Statistical Office 
(CSO) and Eurostat were the sources of empirical data. The study employed a comparative method, an analysis of the growth rate and an analysis of the average rate of change using the geometric mean. Spearman's rank correlation coefficient was used to determine the correlation of the analysed variables.

\section{RESULTS AND DISCUSSION}

The factor that increases the difficulty of achieving the optimal use of production resources in agriculture in Poland is the unfavourable area structure of farms. However, in 2002-2016 there were significant changes towards the concentration of agrarian structure, resulting from several processes. One of those unfavourable factors was the considerable decrease in utilised agricultural area, reaching 1.92 million ha UAA, i.e. $11.4 \%$ in relation to utilised agricultural area from 2002 (Table 1). It should be emphasised, however, that in the said period the average rate of decrease in utilised agricultural area was $0.86 \%$, while in 1990-2001 it had been $1.11 \%$. The rate at which land was removed from agricultural use slowed down in 2004, i.e. with Poland's accession to the EU and the introduction of the CAP, particularly direct payments. The slow but continuous progress in the concentration of agrarian structure resulted from the fact that the decrease in utilised agricultural area in 2002-2016 was accompanied by a much greater decrease in the number of farms (with an area of more than 1 ha of UAA), of as much as $29 \%$. Every year the number of farms dropped by $2.42 \%$, which was nearly 3 times faster than the decrease in utilised agricultural area. As a result, average farm area increased in 2002-2016 by as much as $27.4 \%$. It should be noted that in 1995-2001 average farm area had increased by only $6.6 \%$. The increased rate of concentration of agrarian structure was also evidenced by the fact that the share of farms with more than 15 ha of UAA in total farms increased by 4.8 p.p. in $2002-2016$ and their

Table 1. Changes in the agrarian structure and labour resources in agriculture in Poland in 2002-2016

\begin{tabular}{|c|c|c|c|c|c|c|c|c|}
\hline \multirow[b]{3}{*}{ Year } & \multirow{3}{*}{$\begin{array}{l}\text { Agricultural } \\
\text { land } \\
\text { (million ha) }\end{array}$} & \multicolumn{2}{|c|}{ Farms* } & \multirow{2}{*}{\multicolumn{2}{|c|}{$\begin{array}{c}\text { Farms over } 15 \text { ha of } \\
\text { UAA* }\end{array}$}} & \multirow{2}{*}{\multicolumn{2}{|c|}{$\begin{array}{l}\text { Employed in agriculture } \\
\text { (in thousands of people) }\end{array}$}} & \multirow{3}{*}{$\begin{array}{l}\text { Labour } \\
\text { inputs } \\
\text { (thous. } \\
\text { AWU) }{ }^{* * * *}\end{array}$} \\
\hline & & \multirow[b]{2}{*}{ number } & \multirow[b]{2}{*}{$\begin{array}{c}\text { average area } \\
\text { (ha of } \\
\text { UAA) }\end{array}$} & & & & & \\
\hline & & & & $\begin{array}{l}\text { percentage } \\
(\%)\end{array}$ & $\begin{array}{l}\text { share in } \\
\text { UAA } \\
(\%)^{*}\end{array}$ & $\begin{array}{c}\mathrm{CSO} \\
\text { estimates }^{* *}\end{array}$ & $\begin{array}{c}\text { Labour } \\
\text { Force } \\
\text { Surveys }^{* * *}\end{array}$ & \\
\hline 2002 & 16.90 & 1956.1 & 8.4 & 10.2 & 44.7 & 2109.0 & 2664 & 2403.5 \\
\hline 2004 & 16.33 & 1856.2 & 8.5 & 10.3 & 46.2 & 2094.7 & 2483 & 2283.6 \\
\hline 2006 & 15.95 & 1810.4 & 8.6 & 11.1 & 51.6 & 2093.3 & 2268 & 2235.9 \\
\hline 2008 & 16.15 & 1810.3 & 8.8 & 11.5 & 52.8 & 2091.6 & 2136 & 2299.3 \\
\hline 2010 & 15.46 & 1484.3 & 9.2 & 13.2 & 56.8 & 2329.9 & 2044 & 1914.8 \\
\hline 2012 & 15.57 & 1477.8 & 10.1 & 14.1 & 58.4 & 2328.0 & 1908 & 1914.8 \\
\hline 2014 & 15.16 & 1381.6 & 10.3 & 14.8 & 59.7 & 2331.4 & 1843 & 1937.1 \\
\hline 2016 & 14.98 & 1387.9 & 10.7 & 15.0 & 60.4 & 2328.6 & 1663 & 1675.8 \\
\hline \multicolumn{9}{|c|}{ Relative increase } \\
\hline$d_{t / c}(\%)$ & -11.4 & -29.0 & 27,4 & - & - & 10.4 & -37.6 & -30.3 \\
\hline
\end{tabular}

* Applies to farms over 1 ha of UAA.

** CSO estimates based on National Agricultural Census and National Census of Population and Housing..

*** The number of employees is the number of people aged $\geq 15$ years old who have worked for at least one hour a week, receiving salary or income for it, i.e. they worked in their own or leased farm.

**** Annual Work Unit - equals to 2,120 working hours per year.

Source: GUS and Eurostat data. 
share in the total utilised agricultural area increased by as much as 15.7 p.p., reaching $60.4 \%$.

As for the labour factor, attempting to precisely and reliably determine the level of employment in agriculture and the scale of outflow of labour resources from this sector is problematic. Different study and classification methods were used for assessing employment in agriculture in official statistics in Poland and across the EU. To determine employment figures in agriculture, Statistics Poland uses only estimated values prepared on the basis of data from the National Census of Population and Housing (2002 and 2011) and the National Agricultural Census (1996 and 2010). Due to these factors, the data on employment in agriculture presented in Statistical Yearbooks published by Statistics Poland for 1995-2002, 2003-2009 and 2010-2016 cannot be directly compared. In sectoral analysis, this leads to problems with determining the scale and direction of changes in labour productivity. A possible solution is to analyse labour efficiency on the basis of estimated labour inputs in agriculture in annual work units (AWU) and also on the basis of Labour Force Surveys (LFS). Data from the said sources is much more 'stable' when compared to data from the Statistical Yearbooks of Agriculture and seem to more accurately illustrate the actual level and trend of changes in labour resources in agriculture in 2002-2016, which was downward. According to estimates based on LFS (Table 1) employment in agriculture in Poland decreased from 2.66 million in 2002 to 1.66 million as at the end of 2016, i.e. by as much as $37.6 \%$. Statistics Poland data on labour inputs in agriculture in terms of AWU indicate that employment in this sector decreased by $30.3 \%$ in this period.

According to Eurostat data between 2008 and 2017 labour inputs in agriculture in Poland decreased by $27.1 \%$, whereas the average decrease in EU-28 was $18.1 \%$. In Poland, the average annual decrease in employment in the same period was $3.45 \%$ and in the whole of the EU $-2.17 \%$. According to the Farm Accountancy Data Network (FADN), labour inputs in an average farm in Poland decreased from 1.76 AWU in 2004 to $1.64 \mathrm{AWU}$ in 2015 , i.e. $6.8 \%$. As FADN data are representative of about 750 thousand economically-strongest commercial farms, an important conclusion can be made that the outflow of labour re- sources from agriculture was mainly in economically weak self-supplying farms. In economically stronger farms, aimed at market output, the reduction in employment was relatively low. Average employment in EU farms dropped in 2002-2016 from 1.66 to 1.53 AWU, i.e. by $7.8 \%$. In comparison to an average farm in the EU, Polish farms have higher labour inputs, but the decreasing trend is similar.

Due to the different rate and scale of decrease in utilised agricultural area and labour inputs in agriculture and also the increased capital inputs in the form of capital expenditures, the relationships between production factors in Polish agricultures were subject to significant changes. In 2002-2016 the average number of hectares of utilised agricultural area per AWU increased by nearly 2 ha of UAA, i.e. by $27.1 \%$ (Table 2). Accordingly, employment in agriculture per 100 ha of UAA decreased. Taking into account labour inputs in AWU, it was a decrease from 14.2 to 11.2 AWU, i.e. by $21.3 \%$. According to LFS data, employment per 100 ha of UAA decreased by $29.6 \%$.

In 2002-2016 a significant growth of investment outlays in agriculture was observed. The average annual growth in the whole studied period was 3.23\%, but directly after Poland's accession to the EU (2004-2008) it was 7.5\%, and in 2011-2015-6.7\%. The increase in capital expenditures contributed to a higher rate of substitution of land and labour by capital in the process of agricultural production. In current book-keeping prices, the gross value of fixed assets in agriculture increased from PLN 110.5 billion in 2002 to PLN 143 billion in 2016, i.e. 29.4\%. Work technical equipment (the gross value of fixed assets in agriculture in PLN/AWU) increased by $60 \%$ in real terms in relation to the value from 2002. As for the rate of technological progress (the gross value of fixed assets in PLN/ha of UAA), the increase in real terms in the studied period was $29.2 \%$ (Table 2).

Structural changes in agriculture in 2002-2016 were accompanied by a noticeable growth in land productivity measured as the volume of final output and market output per 1 ha of UAA (Table 3). As for final output, its nominal value in 2016 was $126.8 \%(43.1 \%$ in fixed prices) higher than in 2002. The average annual growth rate of land productivity expressed by final output was $6.02 \%$ in nominal terms and $2.59 \%$ 
Proceedings of the 2018 International Scientific Conference 'Economic Sciences for Agribusiness and Rural Economy' No 2, Warsaw, 7-8 June 2018, pp. 109-115

Table 2. Relationships between production factors in agriculture in Poland in 2002-2016

\begin{tabular}{|c|c|c|c|c|c|}
\hline \multirow{2}{*}{ Year } & $\begin{array}{c}\text { Utilised agricultural } \\
\text { area } \\
\text { per 1 AWU } \\
\text { (ha) }\end{array}$ & $\begin{array}{c}\text { Gross value of fixed assets in constant } \\
\text { prices (prices of 2016) per: }\end{array}$ & $\begin{array}{c}\text { AWU number } \\
\text { per 100 ha of UAA }\end{array}$ & $\begin{array}{c}\text { Employees number } \\
\text { per 100 ha of UAA } \\
\text { (according to LFS) }\end{array}$ \\
\cline { 3 - 5 } & 7.03 & 7612.9 & 53534.2 & 14.2 & 15.8 \\
\hline 2002 & 7.15 & 7641.6 & 54645.8 & 14.0 & 15.2 \\
\hline 2004 & 7.13 & 7948.0 & 56698.0 & 14.0 & 14.2 \\
\hline 2006 & 7.02 & 7786.2 & 54688.8 & 14.2 & 13.2 \\
\hline 2008 & 8.07 & 8728.7 & 67739.9 & 12.4 & 13.2 \\
\hline 2010 & 8.13 & 8917.5 & 69717.6 & 12.3 & 12.3 \\
\hline 2012 & 7.83 & 9633.0 & 72405.6 & 12.8 & 12.2 \\
\hline 2014 & 8.94 & 9832.1 & 85319.3 & 11.2 & 11.1 \\
\hline 2016 & 27.1 & 29.2 & 59.4 & -21.3 & -29.6 \\
\hline$d_{t / c}(\%)$ & & & & & 1 ALN $)$ \\
\hline
\end{tabular}

Source: own calculations based on data as in Table 1 .

in real terms. Land productivity expressed as the volume of market output per 1 ha of UAA increased in $2002-2016$ by $136.8 \%$ in nominal terms $(49.3 \%$ in real terms). The average annual growth rate in market output was significant, as in this period it amounted to $6.35 \%(2.9 \%$ in fixed prices). Labour productivity expressed as the value of final output per AWU increased in the studied period by $91.1 \%$ in nominal terms and by $20.6 \%$ in real terms. The average annual growth rate was lower than in the case of land productivity and amounted to $4.74 \%$ (1.34\% in fixed prices). The increase in labour productivity expressed in the volume of market output was slightly higher than for final output (Table 3). The average annual growth rate of market output (in PLN/AWU) was $5.05 \%$ in nominal terms and $1.65 \%$ in real terms.

Table 3. Land and labour productivity in Polish agriculture in 2002-2016

\begin{tabular}{|c|c|c|c|c|c|c|c|c|}
\hline \multirow{2}{*}{ Year } & \multicolumn{2}{|c|}{$\begin{array}{c}\text { Final output per 1 ha of } \\
\text { UAA (PLN) }\end{array}$} & \multicolumn{2}{|c|}{$\begin{array}{c}\text { Market output } \\
\text { per 1 ha of UAA (PLN) }\end{array}$} & $\begin{array}{c}\text { Final output per 1 AWU } \\
\text { (PLN thous.) }\end{array}$ & \multicolumn{2}{c|}{$\begin{array}{c}\text { Market output per } \\
\text { 1 AWU (PLN thous.) }\end{array}$} \\
\cline { 2 - 9 } & $\begin{array}{c}\text { current } \\
\text { prices }\end{array}$ & $\begin{array}{c}\text { prices of } \\
2016\end{array}$ & $\begin{array}{c}\text { current } \\
\text { prices }\end{array}$ & $\begin{array}{c}\text { prices of } \\
2016\end{array}$ & $\begin{array}{c}\text { current } \\
\text { prices }\end{array}$ & $\begin{array}{c}\text { prices of } \\
2016\end{array}$ & $\begin{array}{c}\text { current } \\
\text { prices }\end{array}$ & $\begin{array}{c}\text { prices of } \\
2016\end{array}$ \\
\hline 2002 & 2591 & 4108 & 2223 & 3525 & 19.2 & 30.4 & 16.5 & 26.2 \\
\hline 2004 & 2709 & 3660 & 2297 & 3103 & 25.5 & 34.4 & 22.1 & 29.9 \\
\hline 2006 & 3021 & 4135 & 2665 & 3648 & 24.6 & 33.7 & 21.9 & 30.0 \\
\hline 2008 & 3622 & 4242 & 3142 & 3679 & 30.4 & 35.6 & 26.9 & 31.5 \\
\hline 2010 & 4044 & 4649 & 3676 & 4226 & 28.6 & 32.9 & 25.5 & 29.3 \\
\hline 2012 & 4855 & 4634 & 4596 & 4387 & 35.1 & 33.5 & 32.2 & 30.7 \\
\hline 2014 & 6280 & 5988 & 5729 & 5463 & 36.8 & 35.1 & 32.9 & 31.4 \\
\hline 2016 & 5877 & 5877 & 5263 & 5263 & 36.7 & 36.7 & 32.9 & 32.9 \\
\hline$d_{t / c}(\%)$ & 126.8 & 43.1 & 136.8 & 49.3 & 91.1 & 20.6 & 99.4 & 25.8 \\
\hline
\end{tabular}

Source: own calculations based on data as in Table 1. 
The analysis of Spearman's rank correlation coefficient indicated that the rate of technological progress and the rate of growth in work technical equipment had a statistically significant $(\mathrm{p}<0.05)$ covariation with the measures of land and labour productivity (expressed in fixed prices). The correlation coefficient between the rate of technological progress and land productivity per 1 ha of UAA assumed positive values -0.91 for final output and 0.94 for market output. The correlation coefficient between work technical equipment and labour efficiency per $1 \mathrm{AWU}$ was statistically significant for market output and amounted to 0.52 .

\section{CONCLUSIONS}

Changes to the agrarian structure and the decrease in employment in Polish agriculture observed in 2002-2016 resulted from the adjustment of the structure of production factors to the changing external and internal determinants. Clearly, an important external factor driving this process was Poland's accession to the EU, which not only necessitated the introduction of institutional adjustments connected with the implementation of the CAP, but also exerted a pressure to increase the economic efficiency of farms to make them more competitive on the market. It is clearly noticeable that the rate of structural changes in agriculture increased since Poland's accession to the $\mathrm{EU}$, which also brought a significant increase in the productivity of production factors in agriculture.

It was found that an increase in land and labour productivity in agriculture was favoured by changes to production structures, which led to a concentration of agrarian structure, improvements in work technical equipment and the rate of technical progress and the outflow of some of the labour resources from agricultural production. A reduction in employment caused a change in the relationship between land and labour towards an increase in utilised agricultural area per full time equivalent in agriculture, a factor that favoured an increase in labour efficiency. This increase would not be possible, however, without considerable investment outlays, which means that the decreasing labour inputs and land resources were replaced by capital inputs.

\section{REFERENCES}

1. Czyżewski, A., Staniszewski, J. (2016). Zastosowanie regresji panelowej dla oceny produktywności i dochodowości w rolnictwie krajów Unii Europejskiej po 2005 roku [The use of a panel regression for the assessment of productivity and profitability in the agriculture of the European Union countries after 2005]. Roczniki Naukowe Ekonomii Rolnictwa i Rozwoju Obszarów Wiejskich, 103 (3), pp. 7-21.

2. Dzun, W. (2012). Zmiany skali wykorzystania zasobów gruntów rolnych w Polsce w procesie przemian systemowych i integracji z Unią Europejską [Changes in the degree of agricultural land use in Poland in view of system changes and European Union integration]. Zagadnienia Ekonomiki Rolnej, 1, pp. 18-39.

3. Fuglie, K., Rada, N. (2013). Growth in Global Agricultural Productivity: An Update. Economic Research Service, USDA.

4. GUS (2002-2017). Rocznik Statystyczny Rolnictwa [Statistical Yearbook of Agriculture]. Dział Wydawnictw Statystycznych GUS, Warszawa.

5. GUS (2003-2016). Użytkowanie gruntów i powierzchnia zasiewów [Land Use and Sown Area]. Dział Wydawnictw Statystycznych GUS, Warszawa.

6. GUS (2006-2016). Aktywność zawodowa Polaków [Economic Activity of the Polish Population]. Dział Wydawnictw Statystycznych GUS, Warszawa.

7. Huffman, W., Evenson, R. (2001). Structural and productivity change in US agriculture, 1950-1982. Agricultural Economics, 24 (2), pp. 127-147.

8. Kusz, D., Misiak, T. (2017). Wpływ technicznego uzbrojenia pracy i postępu technicznego na wydajność pracy w rolnictwie [Influence of work technical equipment and technical progres labour on efficiency in agriculture]. Roczniki Naukowe SERiA, 19 (2), pp. 145-150.

9. Pawlak, J. (2016). Nakłady inwestycyjne w rolnictwie polskim [Investment outlays in Polish agriculture]. Zagadnienia Ekonomiki Rolnej, 3, pp. 143-158.

10. Vandermeulen, V., Mettepenningen, E., Calus, M. (2010). Sectoral mobility of production factors in agriculture and prediction for the future. Selected paper prepared for presentation at 114th EAAE seminar: Structural change in agriculture, Berlin.

11. Wang, S.L., Heisey, P., Schimmelpfennig, D., Ball, E. (2015). U.S. Agricultural Productivity Growth: The Past, Challenges, and the Future. ERS USDA.

12. Wang, S.L., Schimmelpfennig, D., Fuglie, K. (2012). Is agricultural productivity growth slowing in western 
Proceedings of the 2018 International Scientific Conference 'Economic Sciences for Agribusiness and Rural Economy' No 2, Warsaw, 7-8 June 2018, pp. 109-115

Europe. In: Fuglie, K., Wang, S.L., Ball, V.E. (eds.) Productivity growth in agriculture: An international perspective. Washington.

13. Wicki, L. (2016). Zmiany produktywności czynników wytwórczych w polskim rolnictwie [Changes in factor productivity in Polish agriculture]. Ekonomika i Organizacja Gospodarki Żywnościowej, 116, pp. 149-160.

14. Woś, A. (1984) Produkcyjność czynników wytwórczych [Productivity of production factor]. In: Encyklopedia ekonomiczno-rolnicza. PWRiL, Warszawa. 